\title{
56. DATA REPORT: CONSOLIDATION TESTING OF PELAGIC OOZES AND SAPROLITIC CLAYS FROM LEG 144 1
}

\author{
Peter R.N. Hobbs, ${ }^{2}$ Horst W. Bohrmann,${ }^{3}$ and Frank R. Rack ${ }^{4}$
}

\begin{abstract}
This paper describes the results of oedometer consolidation tests conducted in the laboratory on whole-round core samples of pelagic ooze and saprolitic clay obtained during Leg 144 at Sites $871,872,873$, and 880. From these results, estimates of overconsolidation ratio and maximum erosion have been made.
\end{abstract}

\section{INTRODUCTION}

During Ocean Drilling Program (ODP) Leg 144, a total of 13 whole-round core samples were allocated to the participating physical properties specialists for post-cruise geotechnical analyses. These were taken from seven boreholes drilled at four guyot sites: Limalok (871), Lo-En (872), Wodejebato (873), and Seiko (880) (see site map preceding title page). Geotechnical testing consisted of a single oedometer consolidation test per sample, conducted at the British Geological Survey. The purpose of these tests was to study the consolidation behavior of the calcareous oozes and saprolitic clays sampled, and to use the consolidation behavior to calculate the maximum previous overburden and hence estimate the maximum thickness of eroded sediment. The test method employed conventional lever-arm, fixed-ring-type oedometers with dead-loads applied at 24-hr intervals. Yield points were constructed from applied stress vs. voids ratio plots and the maximum previous overburden calculated. It was also possible, from the consolidation data, to make an estimate of the liquid permeability of the samples. These factors are of interest in sedimentological studies and may be correlated with on-board laboratory and downhole parameters. Consolidation data for the calcareous oozes are of particular interest because they are affected by the structural features of individual fossil skeletons as well as by their packing. The foraminifer oozes are particularly homogeneous and well sorted, with intact skeleton sizes, based on limited microscopic observations, of $200-600 \mu \mathrm{m}$ (medium sand). The nannofossil oozes are less homogeneous, with a typical intact skeleton size range of about 5-20 $\mu \mathrm{m}$. Both types of ooze have a very high carbonate content. The nannofossil oozes usually contain a considerable proportion of foraminifers, resulting in a less well-sorted ooze compared with the typical foraminifer ooze. This poor sorting is generally reflected in a denser packing, and hence a slightly lower porosity, for the nannofossil oozes than for the foraminifer oozes.

The technique of one-dimensional oedometer consolidation testing and its interpretation is well established in the fields of terrestrial geotechnics and marine sedimentology (Crawford, 1964; Skempton, 1970; Bryant et al., 1974). In particular, studies of marine clays and argillaceous oozes have used the technique (Bryant and Bennett, 1988). Although few studies have been made of the consolidation

\footnotetext{
' Haggerty, J.A., Premoli Silva, I., Rack, F., and McNutt, M.K. (Eds.), 1995. Proc. $O D P$, Sci. Results, 144: College Station, TX (Ocean Drilling Program).

2 British Geological Survey, Engineering Geology and Geophysics Group, Keyworth, Nottingham NG12 5GG, United Kingdom.

${ }^{3}$ Waitzstrasse 67, D-24105 Kiel, Federal Republic of Germany.

${ }^{4}$ Ocean Mapping Group, Department of Geodesy and Geomatics Engineering, University of New Brunswick, Fredericton, NewBrunswick E3B 5A3, Canada.
}

properties of purely calcareous oozes, some recent investigations of marine samples have been made by Demars (1982), Bennett et al. (1989), and Rack et al. (1993).

\section{METHODS}

Samples of pelagic carbonate ooze were obtained with the advanced hydraulic piston corer (APC), whereas samples of saprolitic clay were obtained with the rotary core barrel (RCB). Samples were cut and sealed as whole-round pieces on board ship and transferred to the United Kingdom, where they were stored in a humidity/temperature controlled room. A single, 19-mm-thick, disk-shaped test specimen was obtained from the center of each preserved whole-round core sample ( $100 \mathrm{~mm}$ long by $66 \mathrm{~mm}$ diameter) by hand-trimming the sample to fit into a steel ring of either 2.5 -in. or $50-\mathrm{mm}$ diameter. The disk specimens were then placed in fixed-ring-type oedometer cells, mounted in standard lever-type loading frames, and loaded to effective stresses of up to $4400 \mathrm{kPa}$ in increments of $24-\mathrm{hr}$ duration. One specimen was loaded to $32,200 \mathrm{kPa}$ in a high-pressure lever-type loading frame. Following the maximum loading increment, unloading increments were applied. The test procedure followed that of British Standards 1377 (1990a) but with different time and stress increments. Specimen axes and applied stresses were parallel to the borehole axis. The cells were flooded, before load application, with distilled, deaerated water.

The results of consolidation testing give the magnitude and rate of compressibility. These are expressed in terms of, respectively, the coefficient of volume compressibility $\left(m_{v}\right)$ and the coefficient of consolidation $\left(c_{v}\right)$. Compressibility is expressed graphically in terms of a reduction in void ratio, $e$ vs. (log) applied stress, $P$ (Fig. 1). The determination of $c_{v}$ is by a graphical construction (Casagrande, 1936). The pelagic oozes are probably at the upper limit of $c_{y}$ for this method (direct permeability measurements on the oedometer specimens were not available).

Determinations of particle density or grain density (numerically equivalent to specific gravity) were made on trimmings from each sample using the pycnometer method described in British Standards 1377 (1990b). Dry density and water contents were determined from the test specimen.

The coefficient of volume compressibility, $m_{v}$ is calculated from the relation:

$$
m_{v}=\frac{\Delta e}{\Delta p}\left(\frac{1}{1+e_{0}}\right) \quad\left(m^{2} / M N\right),
$$

where $\Delta e=$ incremental change in voids ratio, $\Delta p=$ incremental change in applied stress in $\mathrm{kPa}$, and $e_{0}=$ void ratio at start of increment. 


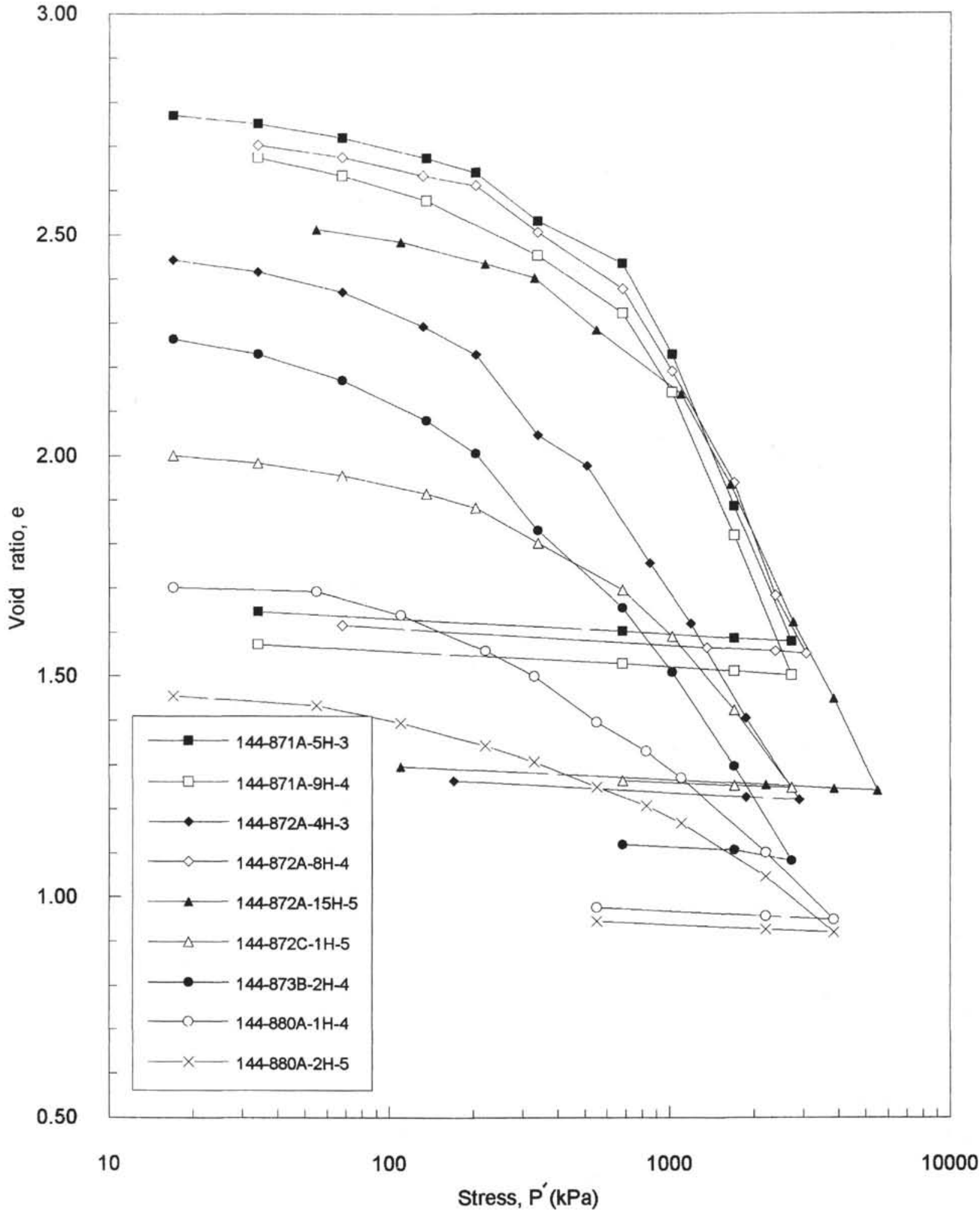

Figure 1. Oedometer consolidation for the pelagic oozes.

Laboratory permeability (in m/s) is derived (after Head, 1994) from the relation:

$$
k_{\text {oed }}=c_{v} \times \rho_{w} \times m_{v} \times 0.31 \times 10^{-9},
$$

where $c_{v}$ is given in $\mathrm{m}^{2} / \mathrm{yr}, m_{v}$ in $\mathrm{m}^{2} / \mathrm{MN}$, and density of water, $\rho_{w}$, in $\mathrm{Mg} / \mathrm{m}^{3}$.
The pre-test void ratio $\left(e_{o}\right)$ is calculated from the relation:

$$
e_{0}=\left(\frac{\rho_{s}}{\rho_{d}}\right)-1,
$$

where $\rho_{s}=$ particle density (or specific gravity) in $\mathrm{Mg} / \mathrm{m}^{3}$, and $\rho_{d}=$ post-test dry density in $\mathrm{Mg} / \mathrm{m}^{3}$. 
Table 1. Results of oedometer consolidation tests.

\begin{tabular}{|c|c|c|c|c|c|c|}
\hline $\begin{array}{l}\text { Core, section, } \\
\text { interval }(\mathrm{cm})\end{array}$ & Site & $\begin{array}{l}\text { Depth } \\
\text { (mbsf) }\end{array}$ & Lithology & $\rho_{\mathrm{s}}$ & $\begin{array}{c}\rho_{d(o)} \\
\left(\mathrm{Mg} / \mathrm{m}^{3}\right)\end{array}$ & $e_{0}$ \\
\hline $144-871 \mathrm{~A}-5 \mathrm{H}-3,140-150$ & Limalok & 40 & Foraminifer ooze & 2.675 & 0.697 & 2.838 \\
\hline $144-871 \mathrm{~A}-9 \mathrm{H}-4,140-150$ & Limalok & 80 & Foraminifer ooze & 2.630 & 0.688 & 2.823 \\
\hline $144-871 \mathrm{C}-6 \mathrm{H}-5,121-131 *$ & Limalok & 180 & Grainstone & 2.603 & 0.642 & 3.055 \\
\hline $144-871 C-33 R-2,135-145$ & Limalok & 430 & Saprolitic clay & 2.991 & 1.163 & 1.572 \\
\hline $144-871 C-33 R-2,135-145 \div$ & Limalok & 430 & Saprolitic clay & 2.991 & 1.220 & 1.452 \\
\hline $144-872 \mathrm{~A}-4 \mathrm{H}-3,140-150$ & Lo-En & 31 & Foraminifer ooze & 2.631 & 0.756 & 2.480 \\
\hline $144-872 \mathrm{~A}-8 \mathrm{H}-4,140-150$ & Lo-En & 69 & Foraminifer ooze & 2.647 & 0.682 & 2.881 \\
\hline $144-872 \mathrm{~A}-15 \mathrm{H}-5,140-150$ & Lo-En & 128 & Foraminifer ooze & 2.667 & 0.746 & 2.575 \\
\hline $144-872 \mathrm{C}-1 \mathrm{H}-5,128-138$ & Lo-En & 5 & Nannofossil ooze & 2.691 & 0.885 & 2.041 \\
\hline $144-873 \mathrm{~A}-13 \mathrm{R}-2,140-150$ & Wodejebato & 168 & Saprolitic clay & 2.564 & 1.254 & 1.045 \\
\hline $144-873 \mathrm{~B}-2 \mathrm{H}-4,140-150$ & Wodejebato & 11 & Nannofossil ooze & 2.702 & 0.816 & 2.312 \\
\hline $144-880 \mathrm{~A}-1 \mathrm{H}-4,140-150$ & Seiko & 5 & Nannofossil-foraminifer ooze & 2.664 & 0.961 & 1.773 \\
\hline $144-880 \mathrm{~A}-2 \mathrm{H}-5,140-150$ & Seiko & 15 & Nannofossil/volcanic ash ooze & 2.700 & 1.083 & 1.493 \\
\hline
\end{tabular}

\begin{tabular}{|c|c|c|c|c|c|c|c|c|c|}
\hline $\begin{array}{l}\text { Core, section, } \\
\text { interval }(\mathrm{cm})\end{array}$ & $\begin{array}{l}n_{o} \\
(\%)\end{array}$ & $\begin{array}{l}w_{o} \\
(\%)\end{array}$ & $\mathrm{C}_{c}$ & $\mathrm{C}_{e}$ & $\begin{array}{l}P_{o}{ }^{\prime} \\
(\mathrm{kPa})\end{array}$ & $\begin{array}{l}P_{c^{\prime}}{ }^{\prime} \\
(\mathrm{kPa})\end{array}$ & $\begin{array}{l}P_{c_{2}} \\
(\mathrm{kPa})\end{array}$ & OCR & $\begin{array}{l}\text { EME } \\
(m)\end{array}$ \\
\hline $144-871 \mathrm{~A}-5 \mathrm{H}-3,140-150$ & 73.9 & 102 & 2.00 & 0.03 & 197 & 580 & 800 & 2.9 & 76 \\
\hline $144-871 \mathrm{~A}-9 \mathrm{H}-4,140-150$ & 73.8 & 101 & 1.50 & 0.03 & 345 & 620 & 860 & 1.8 & 64 \\
\hline $144-871 \mathrm{C}-6 \mathrm{H}-5,121-131 *$ & 75.3 & 110 & & & & & & & \\
\hline $144-871 \mathrm{C}-33 \mathrm{R}-2,135-145$ & 61.1 & 43 & 0.35 & 0.10 & 3826 & & & & \\
\hline $144-871 \mathrm{C}-33 \mathrm{R}-2,135-145 \dagger$ & 59.2 & 43 & 0.75 & 0.21 & 3826 & 6400 & & & 289 \\
\hline $144-872 \mathrm{~A}-4 \mathrm{H}-3,140-150$ & 71.3 & 91 & 1.05 & 0.04 & 129 & 340 & 540 & 2.6 & 50 \\
\hline $144-872 \mathrm{~A}-8 \mathrm{H}-4,140-150$ & 74.2 & 103 & 1.25 & 0.03 & 302 & 540 & 930 & 1.6 & 55 \\
\hline $144-872 \mathrm{~A}-15 \mathrm{H}-5,140-150$ & 72.0 & 93 & 1.20 & 0.03 & 518 & 700 & 1160 & 1.4 & 51 \\
\hline $144-872 \mathrm{C}-1 \mathrm{H}-5,128-138$ & 67.1 & 76 & 0.83 & 0.03 & 26 & 540 & 800 & 19.6 & 93 \\
\hline $144-873 \mathrm{~A}-13 \mathrm{R}-2,140-150$ & 51.1 & 43 & 0.41 & 0.15 & 946 & 3300 & & & 418 \\
\hline $144-873 \mathrm{~B}-2 \mathrm{H}-4,140-150$ & 69.8 & 89 & 1.05 & 0.05 & 53 & 460 & 820 & 8.7 & 85 \\
\hline $144-880 \mathrm{~A}-1 \mathrm{H}-4,140-150$ & 63.9 & 64 & 0.60 & 0.03 & 36 & 280 & 1050 & 7.8 & 34 \\
\hline $144-880 \mathrm{~A}-2 \mathrm{H}-5,140-150$ & 59.9 & 58 & 0.53 & 0.03 & 99 & 500 & 1300 & 5.1 & 61 \\
\hline
\end{tabular}

Notes: An asterisk $\left(^{*}\right)$ indicates that test failed, and a dagger $(\dagger)$ indicates a high-pressure test. $\rho_{s}=$ particle density or grain density $\left(=\right.$ specific gravity); $\rho_{d(o)}=$ pre-test dry density; $e$ $=$ pre-test void ratio; $n_{o}=$ pre-test porosity; $w_{o}=$ pre-test water content; $C_{c}$ and $C_{e}=$ compression and rebound indices, respectively; $P_{o}{ }^{\prime}=$ effective overburden stress; $P_{c_{1}}{ }^{\prime}=$ fir: yield-point stress (derived from the $e-\log P$ plot); $P_{c_{2}}{ }^{\prime}=$ second yield-point stress (derived from the $e-\log P$ plot); OCR =overconsolidation ratio; and EME = estimated maxi mum erosion.

The porosity $(n)$ is related to the void ratio $(e)$ as follows:

$$
n=100 \times\left(\frac{e}{1+e}\right)
$$

The overconsolidation ratio (OCR) is calculated as follows:

$$
\text { OCR }=\frac{P_{c_{1}}^{\prime}}{P_{o}^{\prime}}
$$

where $P_{c_{1}}{ }^{\prime}=$ the first yield-point effective stress in $\mathrm{kPa}$, and $P_{o}^{\prime}=$ the estimated present effective overburden stress in $\mathrm{kPa}$.

The estimated maximum erosion (EME) in meters is calculated as follows:

$$
\mathrm{EME}=(\mathrm{OCR} \times d)-d
$$

where $d=$ the present sample depth in mbsf.

Sample disturbance is a significant factor when using the advanced piston corer (APC). Essentially, this type of drill penetrates the sediment with a sudden thrust. The result in the case of loose or poorly cemented, noncohesive oozes is severe disturbance. Evidence of liquefaction (piping and turbulence) was observed to result from drilling, handling, and subsampling. Although some weak cementing of the oozes was noted on opening up the samples, it may be the case that recementing following moisture loss had taken place. The situation was different for the saprolitic clays owing to their density and cohesion, and the use of the rotary core barrel (RCB). Nevertheless, considerable disturbance is suspected.

\section{DISCUSSION}

Data in Table 1 are summarized from Jones and Hobbs (1994). Pre-test void ratios (Table 1) range from 1.49 to 3.06 , the lowest and highest values being for the nannofossil/volcanic ash ooze and the grainstone samples, respectively. Values of pre-test void ratio for the saprolitic clays range from 1.05 to 1.57 . Values of particle or grain density are notably high in the case of the saprolitic clays, although not as high as the values reported from the on-board results using a different method (Shipboard Scientific Party, 1993a, 1993b).

Figures 1 and 2 show void ratio vs. (log) stress plots for the pelagic ooze and the saprolitic clay samples, respectively. These plots were used to produce the yield points given in Table 1 . The yield point is defined here as the value of $P_{c}^{\prime}$ derived from the Casagrande (1936) construction on the $e-\log P$ plot. The plots show that for the pelagic oozes there are two yield points, the clarity of which varies from sample to sample. In the case of the saprolitic clays, only one yield point can be seen. Yield points for the pelagic oozes lie within the stress range $280-1160 \mathrm{kPa}$. These are shown together with the estimated present overburden stress in Figure 3. This shows that the first yield points tend to have a more discernible trend of increase with depth than the second yield points, and are therefore more likely to reflect increasing effective overburden stress rather than lithological differences or sample disturbance. Yield-point stresses for the two saprolitic clays tested are 3300 and $6400 \mathrm{kPa}$.

The OCR relates the estimated present effective overburden stress $\left(P_{o}{ }^{\prime}\right)$ to the maximum previous effective overburden stress $\left(P_{c}^{\prime}\right)$. Here, this has been taken to be represented by the first yield point $\left(P_{c_{1}}{ }^{\prime}\right)$. Values obtained for OCR are given in Table 1 and Figure 4 . In the case of the saprolitic clays, which are residual deposits derived from subaerial weathering of basalts, the OCR is not an appropriate concept and has been omitted from Table 1. Present effective overburden stress $\left(P_{o}{ }^{\prime}\right)$ has been calculated from the density information in Shipboard Scientific Party (1993a, 1993b). The figure for estimated maximum erosion (Table 1) has been calculated assuming that the material eroded had the same average density as that of the present overburden. Clearly, for saprolitic clays such a calculation is highly speculative; for pelagic oozes, however, it is probably not unreason- 


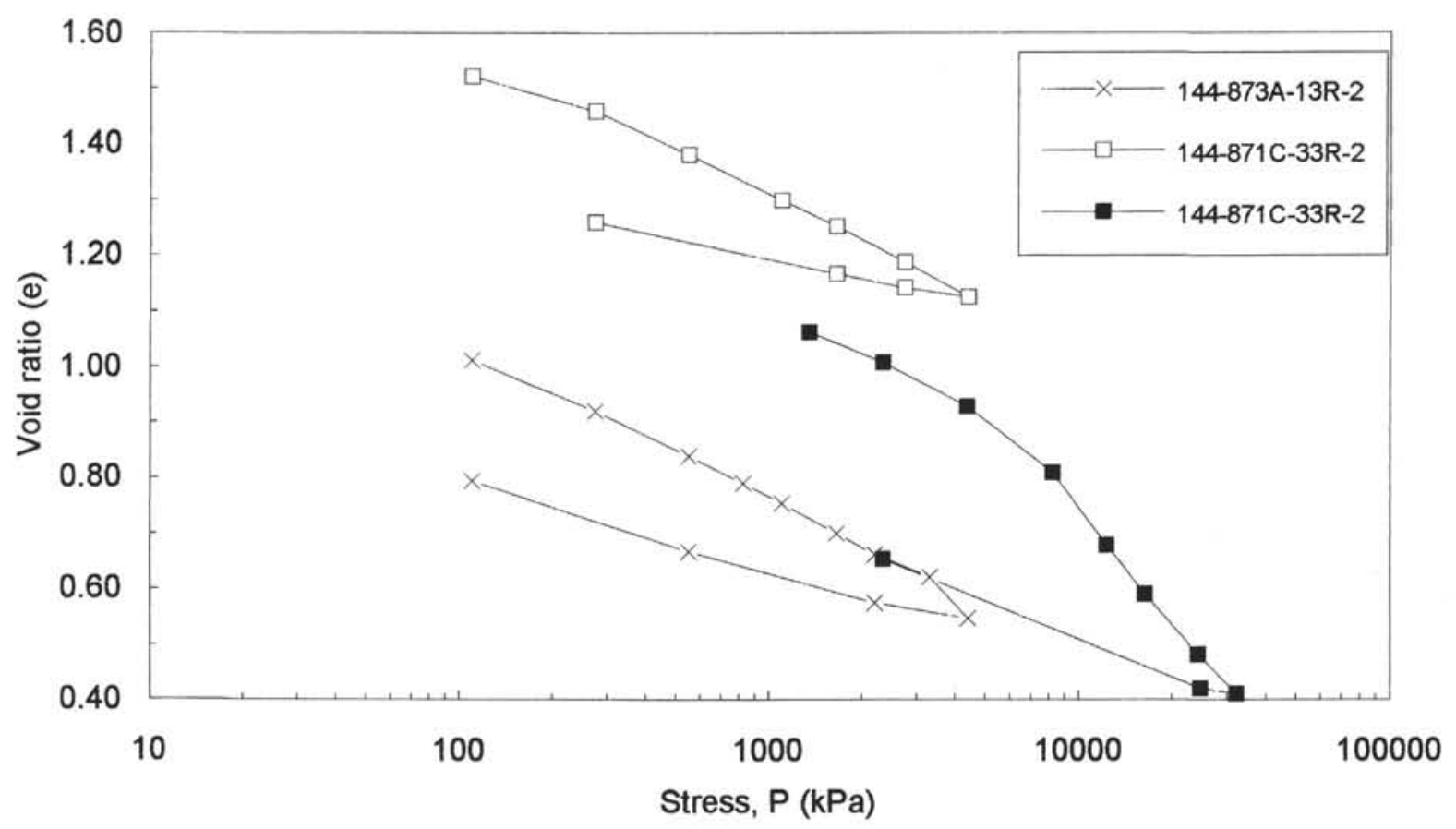

Figure 2. Oedometer consolidation for the saprolitic clays.

able. The results give estimated maximum erosions for pelagic oozes from 34 to $93 \mathrm{~m}$ (Fig. 5). The three values of estimated maximum erosion for Hole $872 \mathrm{~A}$ (Lo-En) are particularly consistent: 50,51 , and $55 \mathrm{~m}$.

The choice of the first yield point to calculate OCR for the pelagic oozes is somewhat arbitrary, as the cause of neither yield point is known. There are three likely causes: (1) the breaking of cementation bonds, (2) a change of packing density, and (3) the crushing of individual tests. A change of packing density does not preclude previous stresses beyond those causing it, for the simple reason of sample disturbance. Similarly, the breakage of any cementation bonds, which may have reestablished themselves in the time between sampling and testing, would not necessarily define the maximum previous stress. The crushing of nannofossil and foraminifer skeletons, however, is an irreversible process that would indicate a maximum previous overburden. Even though the second yield stresses may be said to be rather low for their cause to be the wholesale crushing of tests, no further yield points were noted, even at applied stresses of up to $5000 \mathrm{kPa}$.

In reality, individual skeletons, being of different sizes, forms, and wall thicknesses, will crush at different stresses, which are difficult to establish experimentally. It is likely that the larger skeletons will crush at lower stresses than the smaller ones. Nannofossil oozes tend to contain individuals with a wider range of skeletal sizes and forms interspersed with a certain proportion of foraminifers, and it is likely that a general crushing of skeletons will be progressive throughout the stress range applied in the oedometer test. Spherical foraminifer tests will tend to be broken by point forces at the contacts with adjacent ones. Collapse of the nonspherical or more complex forms of nannofossil will be less predictable.

Tropical saprolitic clays tend to have distinct micro/macro structures where the clay particles are aggregated into silt-sized "peds" or around weathered, sand-sized rock fragments (Vaughan, 1988). The single yield point observed is probably caused by the bonds breaking between peds.

The oedometer results show similar $e$ vs. $\log P$ plots for foraminifer and nannofossil oozes, albeit with differing pre-test void ratios, whereas those for the nannofossil/foraminifer and nannofossil/volcanic ash oozes are of a different form. The plot for the nannofossil/ volcanic ash ooze, a slightly cohesive sediment with a low void ratio, is suggestive of sample disturbance. The pre-test void ratios (Table 1) are lower for the nannofossil oozes than for the foraminifer oozes, presumably because of the former's poorer sorting and hence higher packing density.

Derivation of laboratory permeability $\left(k_{\text {oed }}\right)$ indirectly from the oedometer results is problematic because of the difficulty in determining $c_{v}$, at low applied stresses in these materials. Values at an applied stress equivalent to the present overburden stress are only available for a few tests. Sample 144-873B-2H-4, 140-150 cm (nannofossil ooze), has a $k_{\text {oed }}$ of $8 \times 10^{-9} \mathrm{~m} / \mathrm{s}$, and Sample 144-880A-2H-5, 140-150 cm (nannofossil/volcanic ash ooze) has a $k_{\text {oed }}$ of $8.5 \times 10^{-9} \mathrm{~m} / \mathrm{s}$. Permeability data are unavailable for the foraminifer oozes at overburden stresses. However, at applied stresses less than the first yield-point stress, Samples 144-872A-4H-3, 140-150 cm, and -8H-4, 140-150 $\mathrm{cm}$, yield $k_{\text {oed }}$ values of $1.4 \times 10^{-10}$ and $3.2 \times 10^{-9} \mathrm{~m} / \mathrm{s}$, respectively. With increasing applied stress, the $k_{\text {oed }}$ values for the foraminifer oozes tend to be erratic, but with an apparent peak occurring at applied stresses from 850 to $2750 \mathrm{kPa}$. Permeabilities derived for the saprolitic clays provide a more complete and reliable record of gradual decrease in $k_{\text {oed }}$ with increasing applied stress. At overburden stress, $k_{\text {oed }}$ values for Samples 144-873A-13R-2, 140-150 cm, and 144-871C-33R-2, $135-145 \mathrm{~cm}$, are $1.5 \times 10^{-11}$ and $4.0 \times 10^{-12} \mathrm{~m} / \mathrm{s}$, respectively.

Vaughan (1988) and Jose et al. (1990) have recommended that ( $\log$ ) void ratio vs. (log) stress plots with a modified graphic construction should be used in preference to the traditional method (Casagrande, 1936). However, the method is not suited to multiple yield points, and the results do not differ from those reported here.

\section{CONCLUSIONS}

As a result of oedometer consolidation tests on pelagic oozes, twin yield points have been identified in all cases, These are attributed to breaking cementation bonds, densification, or crushing tests, or a combination of these factors. Of these, crushing tests is probably the least likely mechanism at the stresses applied. The yield points have been used to estimate the maximum erosion undergone by the sediments. This ranges from 34 to $93 \mathrm{~m}$. The estimates for Lo-en Hole $872 \mathrm{~A}$ are consistent with each other. The estimates for Limalok and Seiko appear to show opposite trends with depth, with the Limalok data most likely to be in error. Such errors are largely a result of 


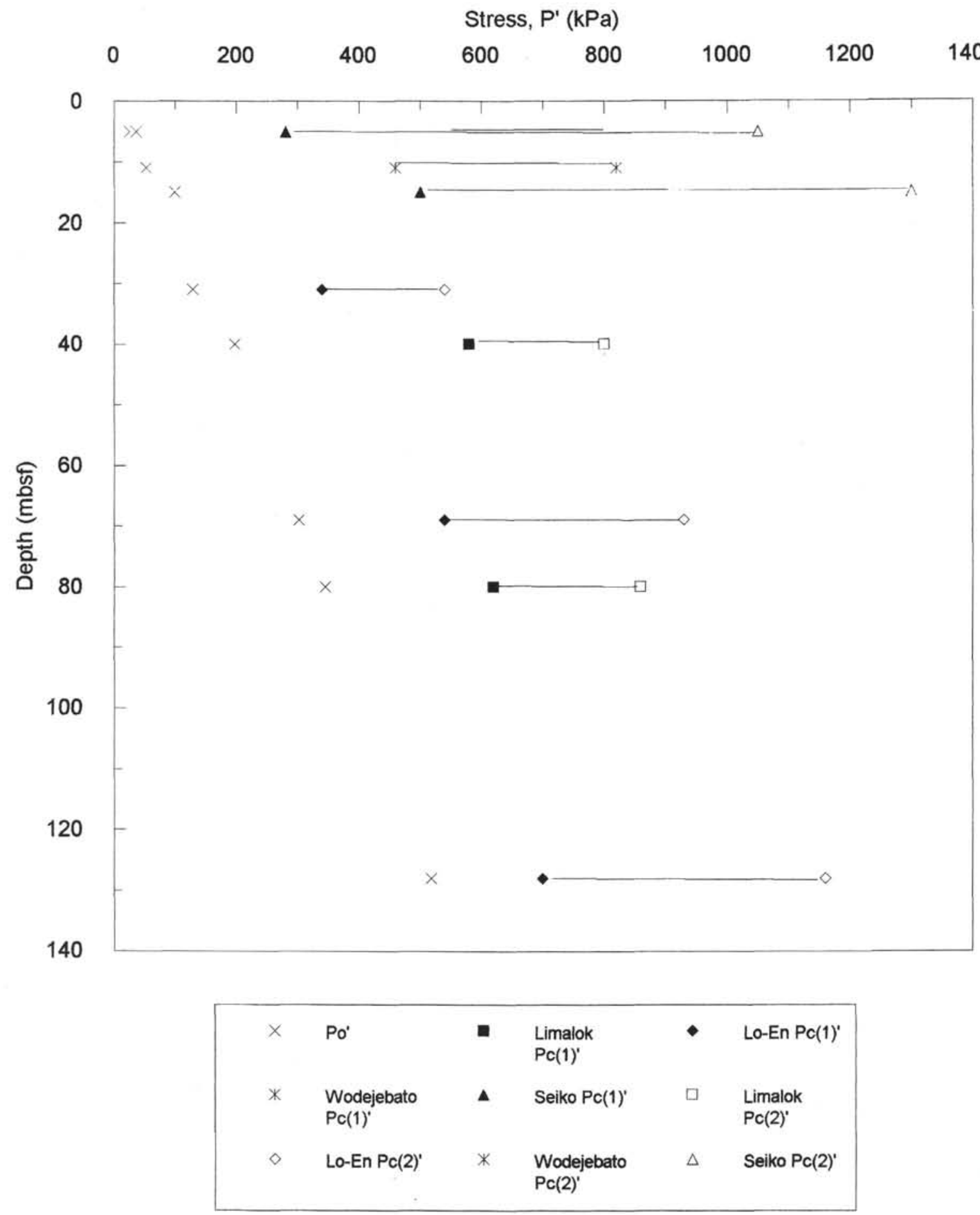

Figure 3. Yield and overburden stresses vs. depth for the pelagic oozes.

the paucity of data. It has not been possible to quantify the effects on the oedometer results of sample disturbance, but observation suggests that disturbance was considerable, particularly for shallow samples of pelagic ooze. There is, therefore, the possibility of a post-sampling reestablishment of cementation bonds with time. In the case of the saprolitic clays, only one yield point has been identified. This is attributed to breaking inter-ped bonds. Values for permeability at equivalent effective overburden stress, derived indirectly from oedometer data, appear to be reasonable, taking into account lithology and depth.

\section{REFERENCES}

Bennett, R.H., Fischer, K.M., Lavoie, D.L., Bryant, W.R., and Rezak, R., 1989. Porometry and fabric of marine clay and carbonate sediments: determinants of permeability. Mar. Geol., 89:127-152.

\footnotetext{
- Abbreviations for names of organizations and publications in ODP reference lists follow the style given in Chemical Abstracts Service Source Index (published by American Chemical Society).
} 
British Standards (BS) 1377, 1990a. Methods of Test for Soils for Civil Engineering Purposes (Pt. 5): Compressibility, permeability, and durability test: London (British Standards Institution).

, 1990b. Methods of Test for Soils for Civil Engineering Purposes (Pt. 2): Classification Tests: London (British Standards Institution).

Bryant, W.R., and Bennett, R.H., 1988. The origin and physical nature of red clays: the Pacific Ocean Basin as a model. Geo-Mar. Lett., 8:189-249.

Bryant, W.R., Deflache, A.P., and Trabant, P.K., 1974. Consolidation of marine clays and carbonates. In Inderbitzen, A.L. (Ed.), Deep-Sea Sediments: Physical and Mechanical Properties (1st ed.): New York (Plenum), 209-244.

Casagrande, A., 1936. The determination of preconsolidation load and its practical significance. Proc. 1st Int. Conf. Soil Mech. and Foundation Eng., Am. Soc. Civ. Eng., 3:60-64.

Crawford, C.B., 1964. Interpretation of the consolidation test. J. Soil Mech. Foundation. Div., Proc., Am. Soc. Civ. Eng., 87-108.

Demars, K.R., 1982. Unique engineering properties and compression behavior of deep-sea calcareous sediments. In Demars, K.R., and Chaney, R.C. (Eds.), Geotechnical Properties, Behavior, and Performance of Calcareous Soils. ASTM Spec. Tech. Publ., 777:97-112.

Head, K.H., 1994. Manual of Soil Laboratory Testing (Vol. 2): Permeability, Shear Strength and Compressibility Tests (2nd ed.): New York (Halsted Press/Wiley).

Jones, L., and Hobbs, P.R.N., 1994. Oedometer consolidation testing of calcareous pelagic oozes and saprolitic clays from ODP Leg 144. Brit. Geol. Surv., Eng. Geol. Geophys. Group, Lab. Rep., 94/1.
Jose, B.T., Sridharan, A., and Abraham, B.M. 1989. Log-log method for determination of preconsolidation pressure. Geotech. Test. J., 12:230-237.

Rack, F.R., Bryant, W.R., and Julson, A.P., 1993. Microfabric and physical properties of deep-sea high-latitude carbonate oozes. In Rezak, R., and Lavoie, D.L. (Eds.), Frontiers in Sedimentary Geology: Carbonate Microfabrics: New York (Springer-Verlag).

Shipboard Scientific Party, 1993a. Site 871. In Premoli Silva, I., Haggerty, J., Rack, F., et al., Proc, ODP, Init. Repts., 144: College Station, TX (Ocean Drilling Program), 41-103.

, 1993b. Site 873. In Premoli Silva, I., Haggerty, J., Rack, F., et al., Proc. ODP, Init. Repts., 144: College Station, TX (Ocean Drilling Program), 145-207.

Skempton, A.W., 1970. The consolidation of clays by gravitational compaction. Q. J. Geol. Soc. London, 125:373-411.

Vaughan, P.R., 1988. Characterising the mechanical properties of in-situ residual soil. 2nd Int. Conf. Geomech. in Trop. Soils, 1:1-17.

Date of initial receipt: 31 January 1994

Date of acceptance: 15 September 1994

Ms 144SR-037 


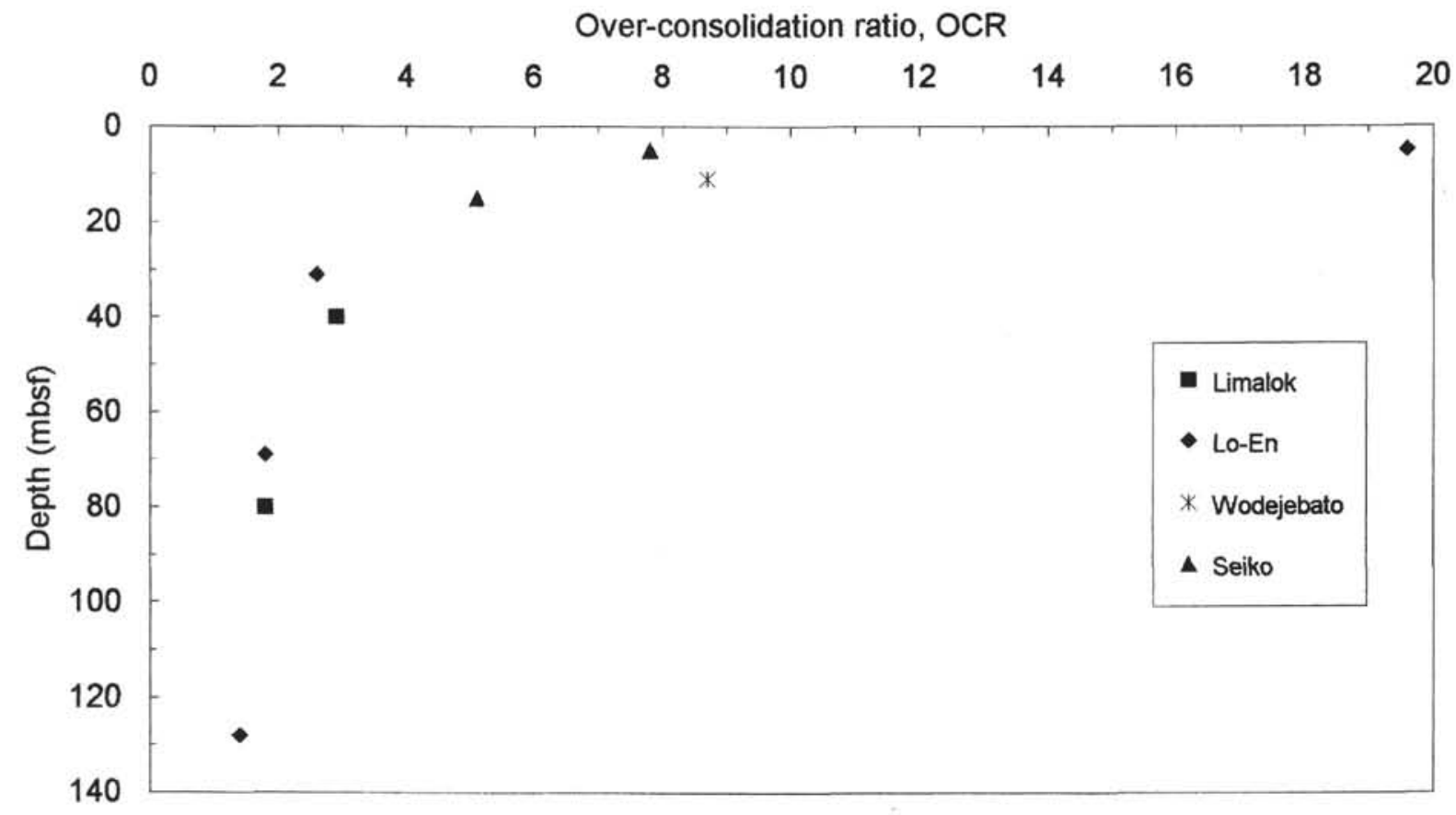

Figure 4. Overconsolidation ratio vs. depth for the pelagic oozes.

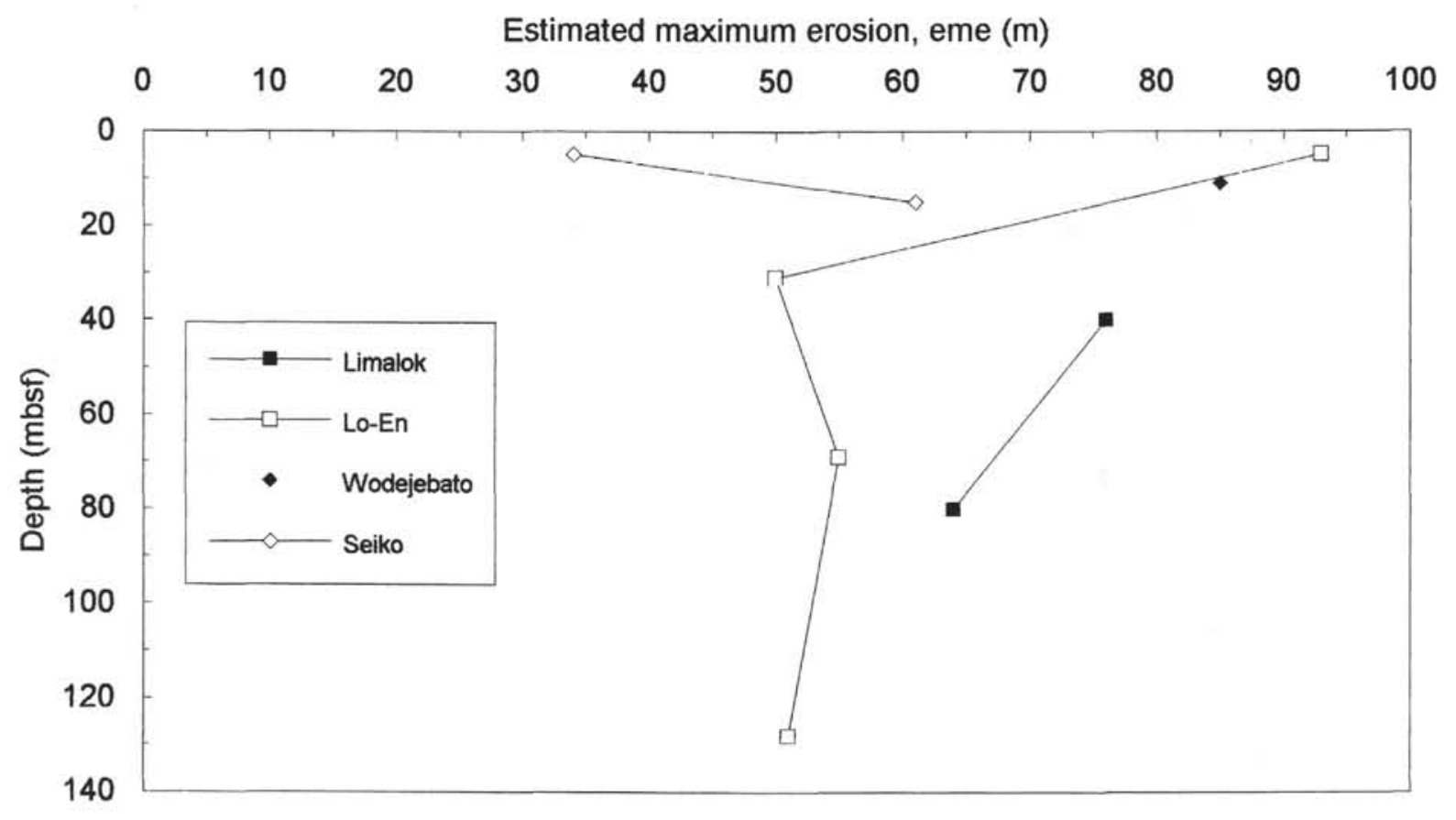

Figure 5. Estimated maximum erosion vs. depth for the pelagic oozes. 